\title{
From waste to energy: Microalgae production in wastewater and glycerol
}

\author{
Iago Teles Dominguez Cabanelas ${ }^{\mathrm{a}, *}$, Zouhayr Arbib ${ }^{\mathrm{a}}$, Fábio A. Chinalia ${ }^{\mathrm{b}}$, Carolina Oliveira Souza ${ }^{\mathrm{d}}$, \\ José A. Perales ${ }^{a}$, Paulo Fernando Almeida ${ }^{c}$, Janice Izabel Druzian ${ }^{d}$, Iracema Andrade Nascimento ${ }^{b}$ \\ a Environmental Technologies Department, CACYTMAR - Centro Andaluz de Ciencia y Tecnología Marinas, University of Cádiz (UCA), Spain \\ ${ }^{\mathrm{b}}$ Marine Biology Lab (LABIOMAR), Biology Institute, University of Bahia, Brazil \\ ' Laboratory of Biotechnology and Ecology of Microorganism (LABEM), Health Sciences Institute, University of Bahia, Brazil \\ ${ }^{\mathrm{d}}$ Department of Bromatological Analysis, Faculty of Pharmacy, University of Bahia, Brazil
}

\section{H I G H L I G H T S}

- Highest biomass and lipid productivities where achieved at mixotrophic cultivation.

- Lipids from mixotrophic biomass were more suitable for biodiesel production.

- Nutrient removal achieved below the most strict threshold limits.

- Positive energy production scenarios can be designed coupling distinct processes.

\section{A R T I C L E I N F O}

\section{Article history:}

Received 5 December 2012

Received in revised form 18 March 2013

Accepted 6 April 2013

\section{Keywords:}

Wastewater

Microalgae production

Mixotrophic

Glycerol

Biorefinery

Energy production

\begin{abstract}
A B S T R A C T
The present work aimed to evaluate the auto/mixotrophic growth of microalgae using domestic wastewater (WW) amended with glycerol aiming biofuels production. The best results were obtained with the highest glycerol supplementation $(50 \mathrm{mM})$. In such condition, Chlorella vulgaris and Botryococcus terribilis showed a biomass productivity of 118 and $282 \mathrm{mg} \mathrm{l}^{-1} \mathrm{~d}^{-1}$, which produced about 18 and $35 \mathrm{mg} \mathrm{l}^{-1} \mathrm{~d}^{-1}$ of lipids, respectively. Thus, if scaled-up $\left(200 \mathrm{~m}^{3} \mathrm{~d}^{-1}\right.$ of $\mathrm{WW}, 240$ working days $\left.\mathrm{y}^{-1}\right)$ biomass and lipid yields may be about 5.6 tons $\mathrm{y}^{-1}$ and $894.2 \mathrm{~kg} \mathrm{y}^{-1}$ or 13.5 tons $\mathrm{y}^{-1}$ and 1.6 tons $\mathrm{y}^{-1}$ for C. vulgaris and B. terribilis, respectively. The mixotrophic production of lipids can generate high quality biodiesel according to estimations using their fatty acids profiles. The whole process can be advantageously combined with the production of other biofuels (e.g. methane and bio-ethanol) in a biorefinery scenario. This combination of algal biomass production with waste treatment (WW amended with glycerol) can have a significant impact in the water treatment sector and local markets.
\end{abstract}

(c) 2013 Elsevier Ltd. All rights reserved.

\section{Introduction}

It is estimated that the volume of domestic effluents generated by North America, Europe and Latin America is of approximately 70,63 and $47 \mathrm{~km}^{3} \mathrm{y}^{-1}$, respectively [1]. Thus, the current main challenge of a Wastewater Treatment Plant (WWTP) is not only to produce reusable clean water, but it is also to find new technologies for supporting such an activity [2]. Conventional techniques can remove only a fraction of the total nitrogen (40\%) and phosphorous (12\%) present in the effluent. In order to improve the process new methods (tertiary steps) and, consequently, additional

\footnotetext{
* Corresponding author. Current address: AlgaePARC (Algae Production and Research Center), Wageningen University and Research Center (WUR), Bornsesteeg 10, Building 112, 6721NG, Bennekom, Netherlands. Tel.: +31 0652896128; fax: +31 0317482631.

E-mail address: iago.dominguezteles@wur.nl (I.T.D. Cabanelas).
}

costs are required [3]. The European Directive 98/15/EC establishes a threshold of 10 and $1 \mathrm{mg}$ per liter for total $\mathrm{N}$ and P. WWTP effluents commonly show $\mathrm{N}$ and $\mathrm{P}$ values around $20-70$ and $4-12$, respectively [3]. Therefore, there is still a clear need for new developments and biological systems are often considered to be the ideal means for responding to such a demand [4]. The economic costs are, however, a primary concern once improved nutrients removal would require an overall increase in energy consumption of about $60-80 \%$ [5]. Therefore, in order to reduce costs, new systems should explore the combination of wastewater treatment with the production of renewable energy in order to offset final costs [6,7].

Microalgae based systems have shown a high potential to assist with nutrient removal [8-10]. On the other hand, such a process can be improved if treatment is associated with generation of valuable co-products [7]. Biofuels have been advocated as a suitable option to replace fossil fuels [11,12]. However, several social and environmental issues are associated with increasing land crops 
based biodiesel and microalgae based systems were identified as capable of overcoming both economic and ecological problems [12-14]. In addition, microalgae systems can generate further commodities such as bio-ethanol, bio-kerosene, bio-plastics, biohydrogen, biogas, and other chemicals derivatives [15-17].

Although microalgae systems show high potential, the main bottleneck toward an effective application in the energy sector is the cost associated with both upstream and downstream processing $[45,12]$. In complement to the commonly explored autotrophic activity, mixotrophic algae systems have also been considered as a viable alternative for supporting innovative bioprocesses $[18,19,11,10]$. Mixotrophic based systems have been previously positively tested for Chlorella and Botryococcus [20-23]. These microalgae genera have been shown to have a high potential for the production of bioenergy and they also have been used for wastewater treatment. However, since the metabolic response may be strain specific, it is still necessary to evaluate their performance and, most importantly, assess their potential lipid yields at such condition.

Finding cheap supplemental carbon sources for algae cultivation is important for minimizing the economic impact. Glycerol, for instance, is currently being produced at significant amounts as the by-product of biodiesel transesterification [24] and, in 2010; the worldwide production was of about 1.8 billion liters [25] with a commercial demand of only 0.8 million per year [24]. Thus, currently, glycerol is cheaply available and with very poor commercial perspectives. Some algae mixotrophic systems have been reported using glycerol as carbon source [11,23,26], but their results regarding biomass and lipid yields are in need of complementation.

Therefore, the use of glycerol as organic supplementation for algal growth is an innovative suggestion and it may significantly contribute to environmental and economic advantages for WWTP worldwide. Thus, the aim of the present work was to evaluate the potential of using glycerol as carbon supplementation to WWTP effluent and its effects on supporting the mixotrophic growth of lipid producing microalgae.

\section{Materials and methods}

\subsection{Microorganism and culture conditions}

Chlorella vulgaris Beijerick 1890 (IBL-C105) and B. terribilis Komaréck 1990 (IBL-C115), which were kept on the Microalgae Bank [13] of the Marine Biology Lab (LABIOMAR) of Federal University of Bahia, Brazil, were prepared using sterilized CHU-13 medium [27]. Trials were operated in 1-1 Erlenmeyer flasks. Seed concentration of $0.2 \mathrm{~g} \mathrm{l}^{-1}$ was used for both strains and operational conditions were as follows: constant shaking (90 bpm), aeration (with $2.5 \%$ $\mathrm{CO}_{2}$ supplementation), photoperiod of $12: 12$ light/dark cycles, luminance of $174 \mu \mathrm{E} / \mathrm{m}^{2} / \mathrm{s}$ and incubation at constant temperature of $25 \pm 1{ }^{\circ} \mathrm{C}$.

\subsection{Experimental set-up}

The domestic effluent was collected after the pretreatment stage (physical removal of large particles and fat materials) at the "Moriçoca" Wastewater Treatment Plant (WWTP) Salvador, Bahia, Brazil. Glycerol $\left(\mathrm{C}_{3} \mathrm{H}_{8} \mathrm{O}_{3}\right)$ was purchased from Synth ${ }^{\circledR}$. The experiments were carried out in triplicates. Glycerol was tested in the following concentrations: $6.25 \mathrm{mM}, 12.5 \mathrm{mM}, 25.0 \mathrm{mM}$ and $50 \mathrm{mM}$. Higher concentrations were not tested once it has been observed an increase of over two-folds in the viscosity of the medium (data not shown). Such an effect affected negatively the cultivation.
Such increase made both growth and harvesting difficult and would mean the inclusion of a confusing variable in the test.

\subsection{Analytical methods}

Microalgae growth was daily monitored by optical density $\left(\mathrm{OD}_{680 \mathrm{~nm}}\right), \mathrm{pH}$, temperature $\left({ }^{\circ} \mathrm{C}\right)$, turbidity (NTU) and total suspended solids $(\mathrm{g} / \mathrm{L})$ [32]. Biomass was recovered by centrifugation $(4500 \mathrm{~g})$ followed by freezing and lyophilization. Algal biomass was also analyzed for (\% dry weight): carbohydrates [28], total lipids [29], chlorophyll $\alpha$ [18], total carotenoids [18] and protein contents [30]

Fatty-acids profile was determined by the capillary column gas chromatographic method applied to the oil methyl esters [31]. The amount of total fatty acids was obtained by transesterification into the corresponding methyl esters (FAME), through saponification with $\mathrm{NaOH}$ in methanol, followed by methylation with BF3 catalyst (12\% in methanol). The FA methyl esters (FAME) were extracted with iso-octane and stored in an inert atmosphere $\left(\mathrm{N}_{2}\right)$ in freezer at $-18^{\circ} \mathrm{C}$. The FAME separation was performed on a gas chromatograph (Varian ${ }^{\circledR} 3800$ ) equipped with a flame ionization detector (GC-FID) and a fused silica capillary column Elite-WAX $(30 \mathrm{~m} \times 0.32 \mathrm{~mm} \times 0.25 \mathrm{~mm})$. The analysis parameters were as described by [33]. The injections were performed in duplicate for each extraction in volume of $1 \mu \mathrm{l}$. FAME's were identified by comparing their retention times with those of authentic standards (189-19, Sigma-Aldrich ${ }^{\circledR}$, USA). The quantification of fatty acids, expressed in $\mathrm{mg} \mathrm{g}^{-1}$ of the samples, was performed with internal standard (C23:0 Sigma ${ }^{\circledR}$, USA). Samples of the wastewater effluents were analyzed (Table 1$)$ for ammonium $\left(\mathrm{N}-\mathrm{NH}_{4}\right)$, nitrate $\left(\mathrm{N}-\mathrm{NO}_{3}\right)$, nitrite $\left(\mathrm{N}-\mathrm{NO}_{2}\right)$, total nitrogen $(\mathrm{TN})$, phosphate $\left(\mathrm{P}_{-}-\mathrm{PO}_{4}\right)$, chemical oxygen demand (COD), $\mathrm{pH}$, conductivity, turbidity and total suspended solids (TSS) according to [32]. Viscosity was assessed by the method of Stokes [33].

\subsection{Data analysis}

Kinetic parameters were estimated using a sigmoid model (Sigma Plot ${ }^{\circledR}$ v.12) as described by Chinalia and Killham [34]. The software is equipped with a statistical package for testing the fitness of the model in describing the biological response. The results are expressed as probability $(p<0.05)$. The kinetic parameters were also crosschecked using linear regression of the exponential phases. Such an approach was applied on the experimental data and their Ln transformed values, respectively.

A parametric analysis of variance (ANOVA) was carried out in order to assess the differences among tested groups. As post hoc test, it was used the Tukey's multiple comparison test (MCT). All analysis were carried out using Graph Pad Instat ${ }^{\circledR}$ software (v. 3, $2008)$, at the significance level of $5 \%(p<0.05)$. Linear regression approach was carried out to assess the correlation between variables (with at least 5 points, $R^{2}$ results are shown in the text).

The year round productivities were calculated based on the results obtained in this research which were scaled-up in order to contemplate a full-scale scenario. Further details of this approach are described by $[35,36]$. The nutrient removal rates were calculated considering the total amounts removed during the incubation period (days). Therefore results are expressed as mg of nutrient removed per day. The assessment of biodiesel quality was carried out based on algal FAMEs profiling as described by Nascimento et al. [13]. 


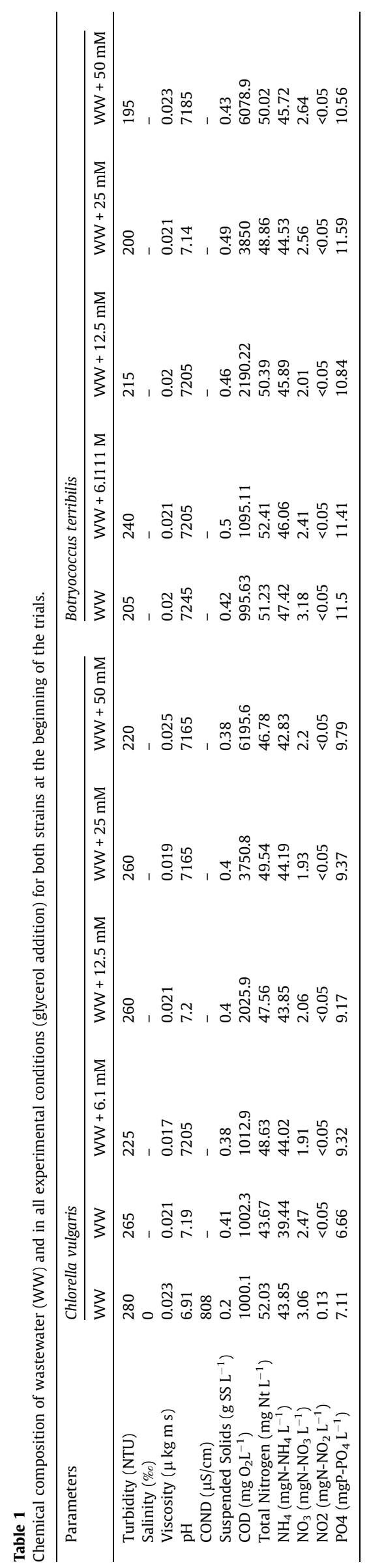

\section{Results and discussion}

\subsection{Biomass production}

Growth kinetic parameters for $C$. vulgaris on wastewater effluent and with distinct glycerol supplementations are shown in Figure $1 \mathrm{~A}$ and Table 2 . Higher values of biomass productivity were observed in the trials with 25 and $50 \mathrm{mM}$ of glycerol (107 and $118 \mathrm{mg} \mathrm{l}^{-1} \mathrm{~d}^{-1}$ ). Liang et al. [21] reported that the glycerol concentration of $100 \mathrm{mM}$ increased $C$. vulgaris biomass productivity in 10folds (from 10 to $102 \mathrm{mg} \mathrm{l}^{-1} \mathrm{~d}^{-1}$ ). The results from the present research, however, showed that glycerol at lower concentrations (6.25 and $12.5 \mathrm{mM}$ ) affected negatively algal productivity when compared to the control (54.2 and $46.4 \mathrm{mg} \mathrm{l}^{-1} \mathrm{~d}^{-1}$, respectively). Low glycerol concentrations $(12.5 \mathrm{mM})$ may trigger mixotrophic metabolism, but it is not enough for supporting an enhanced production of algal biomass. On the other hand, productivity was higher at glycerol concentrations of 25 and $50 \mathrm{mM}$.

Growth kinetics parameters for $B$. terribilis on wastewater amended with glycerol are shown in Figure 1B and Table 2. Different from $C$. vulgaris, the ability of this former species to support biological processes has not yet been comprehensively tested. Similarly to $C$. vulgaris, growth was negatively affected at low glycerol concentrations. Recently, Nascimento et al. [13] have reported relatively higher biomass productivity grown autotrophically (200 $\mathrm{mg} \mathrm{l}^{-1} \mathrm{~d}^{-1}$ ). In the present study, B. terribilis showed a biomass productivity of about 224 and $282 \mathrm{mg} \mathrm{l}^{-1} \mathrm{~d}^{-1}$ with wastewa-

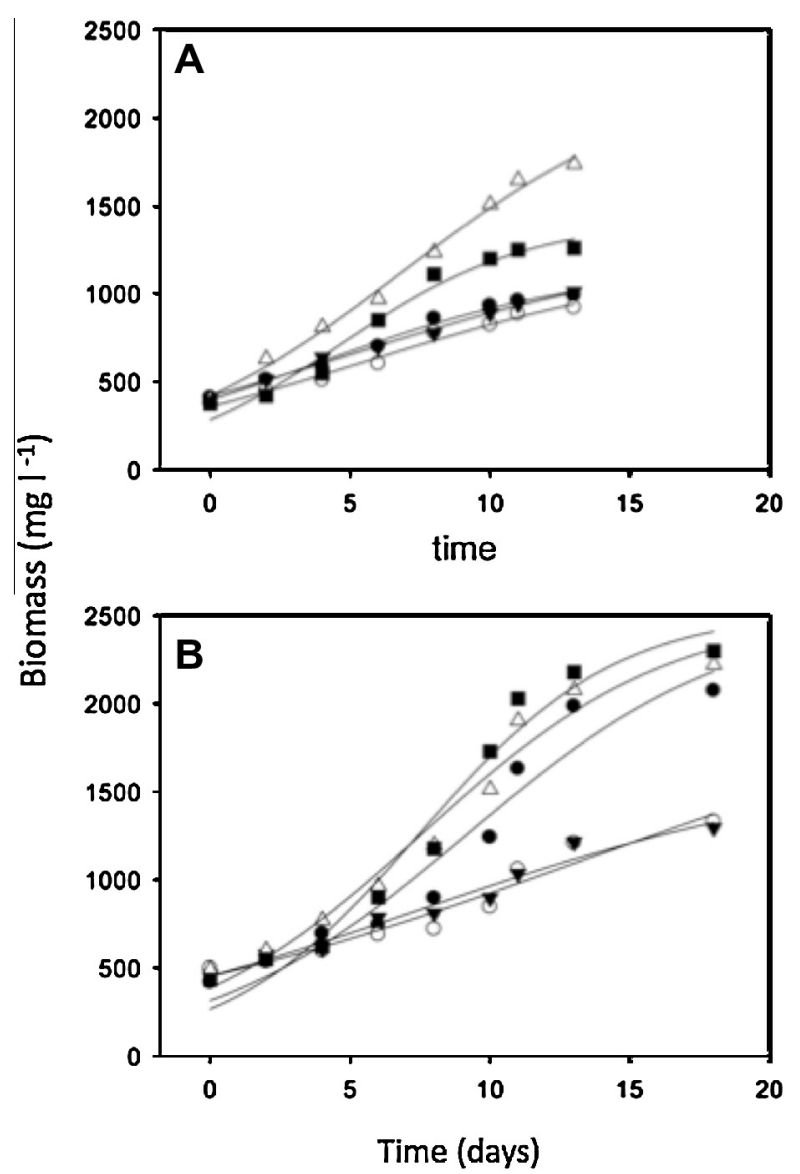

Fig. 1. Growth curves of the strains at all tested conditions: Chlorella vulgaris in wastewater $(W W) \mathbf{\nabla}$, with glycerol addition of $6.1 \mathrm{mM} \circ, 12.5 \mathrm{mM} \bullet 25 \mathrm{mM} \triangle$ and $50 \mathrm{mM}$ (A) and Botryococcus terribilis in wastewater (WW) $\bullet$, with glycerol addition of $6.1 \mathrm{mM} \bigcirc, 12.5 \mathrm{mM} \nabla, 25 \mathrm{mM} \triangle$ and $50 \mathrm{mM} \mathbf{~ ( B )}$. 


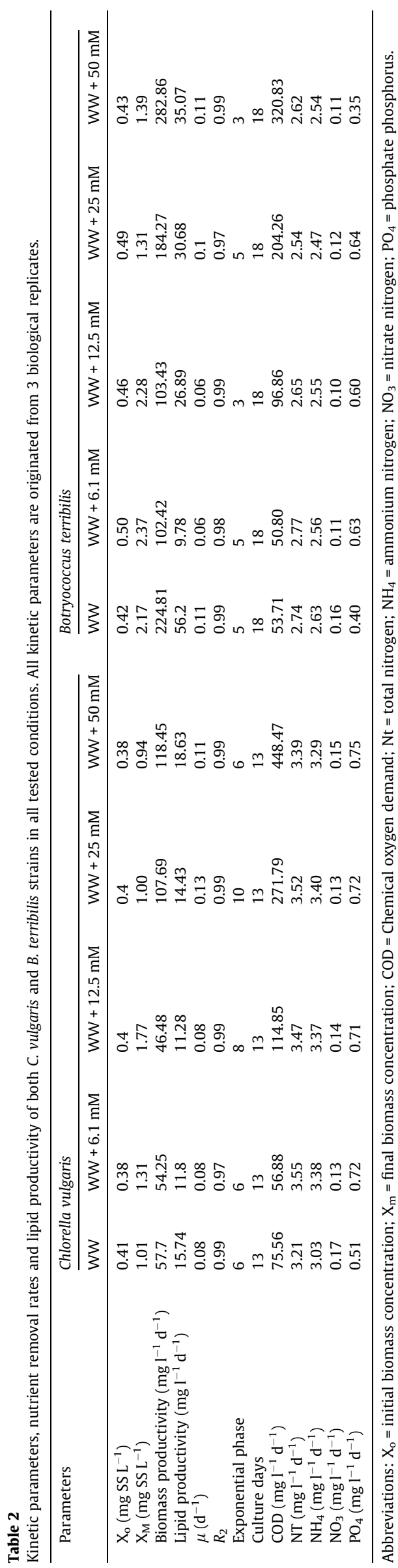

ter effluent (WW) supplemented with glycerol (WW + $50 \mathrm{mM})$. Biomass production of the Botryococcus genus is among the highest reported in the literature [38]. It has been shown that Botryococcus biomass productivity may vary from 19 to $195 \mathrm{mg} \mathrm{l}^{-1} \mathrm{~d}^{-1}$ under autotrophic or heterotrophic conditions $[39,20,39]$. In the present work, biomass production of B. terribilis was over $200 \mathrm{mg} \mathrm{l}^{-1} \mathrm{~d}^{-1}$ in either autotrophic or mixotrophic conditions supplemented with $50 \mathrm{mM}$ glycerol.

\subsection{Nutrient removal}

COD removal ratios were higher than $70 \%$ (Table 2). There is clear linear correlation between glycerol concentrations and COD removal rates $\left(R^{2}=0.98\right)$, a product of the mixotrophic growth. Similar COD removal ratios have been observed previously $[35,40,41]$. However, the values reported by this research are significantly higher than what has been found elsewhere $[42,43]$. It is worth noticing that COD removal rates at high glycerol concentrations reached efficiencies of about $73 \%$ at a starting point of 3500 and $6000 \mathrm{mg} \mathrm{l}^{-1} \mathrm{O}_{2}$ (Table 2). In some cases, COD effluent values generated by the mixotrophic system ( 25 and $50 \mathrm{mM}$ ) were above the legal thresholds regulated by the European Directive. The common WWTP response in such cases is to recirculate the effluent through the aerobic treatment stage. It should be highlighted, however, that the supplementation of glycerol has also increased COD removal rates and the production of a valuable product, oil-rich algae biomass. In addition, it was observed almost complete removal of $\mathrm{N}$ and $\mathrm{P}$. Therefore the gains with this process are very advantageous.

B. terribilis and $C$. vulgaris showed very similar nitrogen removal rates, about $3.4 \mathrm{mg} \mathrm{l}^{-1} \mathrm{~d}^{-1}$, with final concentrations below $10 \mathrm{mg} \mathrm{l}^{-1}$ (Table 2). This value corresponds to the accepted threshold regulated by the European directive 98/15/EC. Phosphorus is rarely a limiting factor when wastewater effluents are used for cultivating algae [4]. Phosphorus removal rates by $C$. vulgaris varied from 0.5 to $0.7 \mathrm{mg} \mathrm{l}^{-1} \mathrm{~d}^{-1}$. B. terribilis showed a lower efficiency in removing phosphorus when compared to $C$. vulgaris (Table 2). The aim is to reach close the target of $1 \mathrm{mg} \mathrm{l}^{-1}$, which is the threshold of the cited European directive. At higher glycerol concentrations (12.5-50 mM) phosphorus removal rate was of $0.6 \mathrm{mg} \mathrm{l}^{-1} \mathrm{~d}^{-1}$, approximately. This is very promising to support strategies for phosphorus removal at tertiary treatment stages. In addition, such a process can also be useful for recovering P [44].

\subsection{Biorefinery possibilities}

Apart from lipids and proteins, full-scale systems based on microalgae can produce other valuable substances [12]. Often, these substances can be produced simultaneously and recovered separately during the production line. In this context several authors suggested an integrating concept which has been defined as algal biorefinery systems $[12,45]$. Such strategy would allow a more efficient exploitation of microalgae-based systems. The main chemical fractions that support the refinery of the algal biomass can be found in Table 3 . Both strains have shown high protein content (60-70\%), but their production did not correlate with increasing glycerol concentrations ( $R^{2}$ of 0.34 and 0.00 for Chlorella and Botryococcus, respectively). C. vulgaris showed a significant correlation between glycerol removal rates and the carbohydrates contents $\left(R^{2}=0.80\right)$. Despite the fact that such response was not observed with Botryococcus terribillis $\left(R^{2}=0.00\right)$, the total amount of carbohydrates where higher for the former than the values observed for the latter (Table 3).

If algal carbohydrates were to be used for ethanol production, for instance, 5.6 and 13.5 tons of algal biomass $\mathrm{y}^{-1}$ could generate 196 and 5061 of ethanol, for Chlorella and Botryococcus, respec- 
Table 3

Biochemical composition of the microalgae strains as percentage of dry weight (\%) and concentration in dry weight ( $\mu \mathrm{g} / \mathrm{mg})$.

\begin{tabular}{|c|c|c|c|c|c|}
\hline \multirow[t]{2}{*}{ Strain/condition } & \multicolumn{5}{|c|}{ Biomass composition } \\
\hline & Carbohydrates (\%) & Total lipids (\%) & Protein (\%) & Chlorophyll $\alpha(\mu \mathrm{g} / \mathrm{mg})$ & Total carotenoids $(\mu \mathrm{g} / \mathrm{mg})$ \\
\hline \multicolumn{6}{|l|}{ C. vulgaris } \\
\hline WW & 3.9a & $27.3 a$ & $65.0 \mathrm{a}$ & $4.71 \mathrm{a}$ & $1.81 \mathrm{a}$ \\
\hline$W W+6.12 \mathrm{mM}$ & $5.2 \mathrm{ab}$ & $21.7 b$ & $70.0 \mathrm{~b}$ & $2.53 b$ & $0.86 \mathrm{~b}$ \\
\hline $\mathrm{WW}+12.5 \mathrm{mM}$ & $5.9 \mathrm{ab}$ & $24.3 a$ & $69.0 c$ & $2.25 b$ & $0.84 \mathrm{~b}$ \\
\hline $\mathrm{WW}+25.0 \mathrm{mM}$ & $6.8 \mathrm{~b}$ & $13.4 \mathrm{c}$ & $69.0 \mathrm{c}$ & $0.20 \mathrm{c}$ & $0.04 \mathrm{c}$ \\
\hline $\mathrm{WW}+50.0 \mathrm{mM}$ & $7.3 \mathrm{~b}$ & $15.7 \mathrm{c}$ & $70.0 \mathrm{~b}$ & $0.25 c$ & $0.04 \mathrm{c}$ \\
\hline \multicolumn{6}{|l|}{ B. terribilis } \\
\hline WW & $7.8 \mathrm{a}$ & $25.0 \mathrm{a}$ & $67.0 \mathrm{a}$ & $3.76 a$ & $0.84 a$ \\
\hline $\mathrm{WW}+6.12 \mathrm{mM}$ & 7.lab & $9.5 b$ & $73.0 \mathrm{~b}$ & $2.66 \mathrm{~b}$ & $0.74 \mathrm{~b}$ \\
\hline $\mathrm{WW}+12.5 \mathrm{mM}$ & $6.2 \mathrm{ab}$ & $26.0 a$ & 67.0a & $1.38 c$ & $0.52 c$ \\
\hline $\mathrm{WW}+25.0 \mathrm{mM}$ & $4.9 \mathrm{~b}$ & $16.7 \mathrm{c}$ & $75.0 \mathrm{c}$ & $0.36 \mathrm{~d}$ & $0.05 d$ \\
\hline $\mathrm{WW}+50.0 \mathrm{mM}$ & 7.9a & $12.4 \mathrm{~d}$ & $68.0 \mathrm{a}$ & $0.19 \mathrm{e}$ & $0.00 \mathrm{~d}$ \\
\hline
\end{tabular}

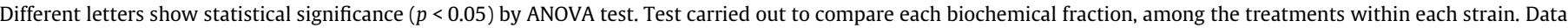
showed are the mean of two replicates. Standard deviations not present because were lower than $10 \%$ for all treatments.

tively (table 5). The algal biomass waste, which is commonly produced during the process of lipid extraction for biodiesel production, can also be used for the co-generation of methane. Table 5 shows that the potential year round production of methane may vary between 1346 and $3258 \mathrm{~m}^{3} \mathrm{y}^{-1}$, for Chlorella and Botryococcus, respectively. It was also observed that glycerol supplementation decreased pigment production for favoring mixotrophic growth. This observation correlates with the obtained values for chlorophyll and carotenoids (Table 3 ).

In this experiment, the accumulation of lipids by $C$. vulgaris varied from $13 \%$ to $27 \%$ of dry weight; and the respective range shown by $B$. terribilis are of $9.5-25 \%$ (Table 3). Although higher lipid contents may have been reported for the Botryococcus genus, it should be highlighted that microalgae accumulation of lipids is a response to environmental and nutritional conditions, none of which have been imposed in the present work. Biodiesel production from microalgae lipids has been the focus of considerable attention in recent years $[16,12]$. Although high glycerol concentration has negatively affected total lipid content per cell for both species, biomass productivity was higher ( 25 and $50 \mathrm{mM}$ ). Thus, as a result, the final total amount of lipid increased in both cases (Table 2). Estimation shows that for treating $200 \mathrm{~m}^{3} \mathrm{~d}^{-1}$ of wastewater it would be necessary $163 \mathrm{~kg}$ of glycerol in a year round treatment strategy (for both strains, Table 5). This represents an attractive solution for a cheap and unappreciated product.

The conversion of lipids into biodiesel is mostly carried out through alcoholic transesterification, and a well-established technology [46]. Therefore, several authors developed a strategy based on the assessment of fatty acids profiling for estimating final biodiesel quality $[13,37,47]$. Base on such an approach, it has been observed that $C$. vulgaris produced significant amounts of long chain isomeric formed FAs (C16 > C18 > C17, Table 4). The percentage of FA in the $C$. vulgaris profile was similar to the values reported elsewhere $[6,4]$, with minor differences in the abundance of C18 isomers. Table 4 also shows the qualitative analyses of FAs (percentages of monounsaturated (MUFA), polyunsaturated (PUFA) and saturated fatty acids (SFA)). Glycerol at low concentrations favoured the synthesis of SFAs. At higher glycerol concentrations (25 and $50 \mathrm{mM}$ ) it was observed a considerable (205 and $122 \mathrm{~kg} \mathrm{y}^{-1}$, Table 5) shift in the FAs profile toward the synthesis of monounsaturated fatty acids (MUFA).

B. terribilis showed the highest ratio of lipid accumulation per biomass (25\%), and, in average, productivity is comparable to that described elsewhere [48]. Other authors have registered similar results, with major differences in the amounts of FAs isomers of C16 to $C 18[13,20,39]$. At lower concentrations, glycerol did not significantly change the FAs-profiles. Mixotrophic condition at high glyc- erol concentration $(50 \mathrm{mM})$ has increased FAs productivity $\left(420 \mathrm{~kg} \mathrm{y}^{-1}\right.$, Table 5) and the ratio of MUFA.

The biodiesel fuel quality depends on the results of the overall fatty acids composition present in the oil [13]. Several countries have already issued basic quality standards for biodiesel production and commercialization based on critical parameters such as: (i) Cetane Number (CN), (ii) Iodine Value (IV), (iii) Cold Filter Plugging Point (CFPP) and (iv) Oxidation Stability (OS). These parameters are a direct assessment of several important biodiesel properties such as ignition readiness, combustion performance, temperature of plugging fuel lines and biological stability during storage. A higher amount of long-chain-SFAs would lead to a biodiesel with elevated cetane number $(\mathrm{CN})$. Biodiesel with higher $\mathrm{CN}$ values show a shorter ignition delay or a better combustion quality. Another parameter, which is also higher in oils rich in SFA, is the saponification values (SV). This refers to the average molecular weight of all FAs, which is measured by the quantity ( $\mathrm{mg}$ ) of potassium hydroxide required to saponify $1 \mathrm{~g}$ of fat. The saponification value varies with the chains-size, the longer the SFAs-chains are, the lower the SV. It is mostly associated with the presence of SFAs (C16, C17 and C18), but in this research saponification values increased for both strains at WW effluent amended with lower glycerol concentrations.

In this study the supplementation of glycerol into the microalgae growth medium has caused an increase in FAs saturation, which consequently resulted in positive alterations on CN, IV, OS. $\mathrm{CN}$ values (data not shown) variations were from 56 to 62 for $C$. vulgaris and from 58 to 67 for B. terribilis, respectively. All treatments are in compliance with the EN $14214 \mathrm{CN}$ (minimum 51, Europe), ASTM D6751-10 (minimum of 47, USA) and RANP-2008 for $\mathrm{CN}$ (minimum of 45 , Brazil). However the best (highest) $\mathrm{CN}$ values for $C$ vulgaris was obtained in the condition of low glycerol concentrations ( 6.1 and $12.5 \mathrm{mM}$ ). In the case of $B$. terribilis, the best value was observed at $25 \mathrm{mM}$ of glycerol supplementation. The calculated CFPP values were positive and showed to be similar to what has been previously reported for these strains [13]. Therefore, the increase in glycerol concentrations may result in a biodiesel with poorer low-temperature flow properties for both species, due to an increase in saturation of long-carbon-chains FAs. These FAs are the first to precipitate if liquid biodiesel is cooled down [13]. Yet, at $50 \mathrm{mM}$ of glycerol supplementation the stearic FA concentration reduced significantly for both species (Table 4). Such results points toward an possible application of this treatment $(50 \mathrm{mM}$ glycerol) for the production of lipids with suitable quality to generate biodiesel for use at moderate temperature locations. It should be highlighted that there are several alternatives yet to be explored for improving the final FAs profiles and, therefore, change the po- 
Fatty acid (FA) profile of both strains at all treatments. Also shown the fatty acid qualitative distribution, total amount of FA in total lipids (TL) and FA percentage in the biomass ( $\mathrm{g}$ per $100 \mathrm{~g}$ of biomass).

\begin{tabular}{|c|c|c|c|c|c|c|c|c|c|c|c|}
\hline \multirow[t]{2}{*}{ Fatty acids (\%) } & & \multicolumn{5}{|c|}{ Chlorella vulgaris } & \multicolumn{5}{|c|}{ Botryococcus terribilis } \\
\hline & & WW & $W W+6.1 \mathrm{mM}$ & $\mathrm{WW}+12.5 \mathrm{mM}$ & $W W+25 \mathrm{mM}$ & $W W+50 \mathrm{mM}$ & WW & $W W+6.1 \mathrm{mM}$ & $\mathrm{WW}+12.5 \mathrm{mM}$ & $w W+25 \mathrm{mM}$ & $\mathrm{WW}+50 \mathrm{mM}$ \\
\hline Butyric & C4:0 & - & 2.29 & - & - & - & 2.45 & - & - & - & - \\
\hline Caprylic & C8:0 & 1.41 & - & - & - & - & 1.92 & - & - & - & - \\
\hline Capric & C10:0 & & - & - & - & - & 2,45 & - & - & - & - \\
\hline Undecanoic & Cll:0 & 0.87 & - & - & - & - & - & - & - & - & - \\
\hline Myristic & C14:0 & 2.06 & - & - & - & - & 2.60 & - & - & - & 1.70 \\
\hline Palmitic & C16:0 & 29.48 & 45.85 & 32.67 & 30.07 & 32.78 & 30.57 & 23.90 & 37.60 & 34.49 & 26.42 \\
\hline Palmitoleic & C16:1 & 1.96 & - & - & & 17.06 & 5.73 & 4.07 & 5.89 & & 2.46 \\
\hline Margaric/heptadecanoic & C17:0 & 7.04 & 24.84 & 25.34 & 2.73 & & 8.16 & 9.95 & 15.46 & 16.62 & 11.44 \\
\hline Heptadecenoic & C17:1 & 5.65 & - & - & 4.31 & - & 3.04 & - & - & - & - \\
\hline Stearic & C18:0 & 12.24 & 29.31 & 22.29 & 14.98 & 16.15 & 12.66 & 14.71 & 6.96 & 20.70 & 13.51 \\
\hline Oleic & C18:1 c & 11.68 & - & 9.66 & 17.59 & 14.85 & 18.37 & 18.00 & 23.12 & 28.19 & 29.21 \\
\hline Elaidic/octadecenoic & C18:It & 1.39 & - & - & 4.67 & 4.21 & - & - & - & - & 4.42 \\
\hline Linoleic & $\mathrm{C} 18: 2 \mathrm{n} 6$ & 13.22 & - & 10.04 & 17.24 & 14.95 & 9.28 & 7.32 & 11.51 & - & 10.84 \\
\hline$\alpha$-linolenic & $\mathrm{C} 18: 3 \mathrm{n} 3$ & 10.24 & - & - & 8.42 & - & - & 7.44 & - & - & - \\
\hline Eicosapentaenoic & $\mathrm{C} 20: 5 \mathrm{n} 3$ & & - & - & - & - & 2.04 & & - & - & - \\
\hline Tetracosenoic & $C 24: \ln 9$ & 2.76 & - & - & - & - & 3.17 & 14.60 & - & - & - \\
\hline \multicolumn{12}{|l|}{ Fatty acids concentration } \\
\hline Saturated (\% FA/TL) & & 53.10 & 100.0 & 80.30 & 47.77 & 48.93 & 59.36 & 48.56 & 59.48 & 71.81 & 53.07 \\
\hline Monounsaturated (\% FA/TL) & & 23.44 & 0.00 & 9.66 & 26.57 & 36.13 & 26.49 & 36.68 & 29.01 & 28.19 & 36.09 \\
\hline Polyunsaturated (\% FA/TL) & & 23.46 & 0.00 & 10.04 & 25.66 & 14.95 & 14.15 & 14.76 & 11.51 & 0.00 & 10.84 \\
\hline $\mathrm{FA}$ total $(\mathrm{mg} / \mathrm{TL})$ & & 2.52 & 0.31 & 0.64 & 1.99 & 1.07 & 1.56 & 0.70 & 1.06 & 1.64 & 1.55 \\
\hline FA total (\% biomass DW) & & 5.05 & 0.77 & 1.29 & 3.98 & 2.15 & 3.20 & 1.41 & 2.10 & 3.29 & 3.10 \\
\hline
\end{tabular}

Table 5

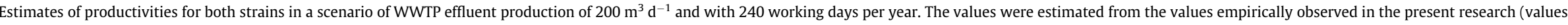
in the table) and the biofuels production options were estimated according with specialized literature (reference given below the table).

\begin{tabular}{|c|c|c|c|c|c|c|c|c|c|c|}
\hline \multirow[t]{2}{*}{ Estimates } & \multicolumn{5}{|c|}{ Chlorella vulgaris } & \multicolumn{5}{|c|}{ Botryococcus terribilis } \\
\hline & WW & $W W+6.1 \mathrm{mM}$ & $W W+12.5 \mathrm{mM}$ & $W W+25 \mathrm{mM}$ & $W W+50 \mathrm{mM}$ & WW & $\mathrm{WW}+6.1 \mathrm{mM}$ & $W W+12.5 \mathrm{mM}$ & $W W+25 \mathrm{mM}$ & $W W+50 \mathrm{mM}$ \\
\hline Biomass productivity (ton $\mathrm{y}^{-1}$ ) & 2.77 & 2.60 & 2.23 & 5.17 & 5.69 & 10.79 & 4.92 & 4.96 & 8.84 & 13.58 \\
\hline Glycerol required $\left(\mathrm{kg} \mathrm{y}^{-1}\right)$ & - & 20.2 & 40.9 & 81.8 & 163.6 & - & 20.2 & 40.9 & 81.8 & 163.6 \\
\hline Lipid productivity $\left(\mathrm{kg} \mathrm{y}^{-1}\right)$ & 755.5 & 566.4 & 541.4 & 692.6 & 894.2 & 2697.6 & 469.4 & 1290.7 & 1472.6 & 1683.4 \\
\hline Total FA $\left(\mathrm{kg} \mathrm{y}^{-1}\right)$ & 139.9 & 20.1 & 28.8 & 205.7 & 122.2 & 345.3 & 69.3 & 104.3 & 291.0 & 420.9 \\
\hline Total carbohydrates $\left(\mathrm{kg} \mathrm{y}^{-1}\right)$ & 108.0 & 135.4 & 131.6 & 351.5 & 415.0 & 841.7 & 349.0 & 307.8 & 433.4 & 1072.6 \\
\hline Biodiesel from TL $\left(\mathrm{kg} \mathrm{y}^{-1}\right)^{\mathrm{a}}$ & 755.5 & 566.4 & 541.4 & 692.6 & 894.2 & 2697.6 & 469.4 & 1290.7 & 1472.6 & 1683.4 \\
\hline Biodiesel from $\mathrm{FA}\left(\mathrm{kg} \mathrm{y}^{-1}\right)^{\mathrm{b}}$ & 139.9 & 20.1 & 28.8 & 205.7 & 122.2 & 345.3 & 69.3 & 104.3 & 291.0 & 420.9 \\
\hline Residual glycerol from TL $\left(\mathrm{kg} \mathrm{y}^{-1}\right)^{\mathrm{c}}$ & 75.5 & 56.6 & 54.1 & 69.2 & 89.4 & 269.7 & 46.9 & 129.0 & 147.2 & 168.3 \\
\hline Residual glycerol ${ }_{\text {from FA }}\left(\mathrm{kg} \mathrm{y}^{-1}\right)^{\mathrm{d}}$ & 13.9 & 2.01 & 2.88 & 20.5 & 12.2 & 34.5 & 6.93 & 10.4 & 29.1 & 42.0 \\
\hline Bio-ethanol $\left(1 \mathrm{y}^{-1}\right)^{\mathrm{e}}$ & 51.0 & 64.0 & 62.2 & 166.1 & 196.1 & 397.6 & 164.9 & 145.4 & 204.8 & 506.7 \\
\hline Methane $\left(\mathrm{m}^{3} l \mathrm{y}^{-1}\right)^{\mathrm{f}}$ & 664.7 & 625.0 & 535.4 & 1240.6 & 1364.5 & 2589.8 & 1179.9 & 1191.5 & 2122.8 & 3258.5 \\
\hline Fertilizer $\left(\mathrm{N} \mathrm{kg} \mathrm{y}^{-1}\right)^{\mathrm{g}}$ & 277.0 & 260.4 & 223.1 & 516.9 & 568.6 & 1079.1 & 491.6 & 496.5 & 884.5 & 1357.7 \\
\hline Fertilizer $\left(\mathrm{P} \mathrm{kg} \mathrm{y}^{-1}\right)^{\mathrm{h}}$ & 27.7 & 26.0 & 22.3 & 51.7 & 56.9 & 107.9 & 49.2 & 49.6 & 88.4 & 135.8 \\
\hline
\end{tabular}

${ }^{a}$ Biodiesel production of $1 \mathrm{~kg}$ per $\mathrm{kg}$ of oil [16]. Here estimated based on full lipids conversion to methyl esters.

${ }^{b}$ Same reference as before. Here estimated based only in the conversion of free fatty acids.

c Glycerol generated in the biodiesel production from total lipids extracted from biomass (conversion rate of $0.1 \mathrm{~kg}$ per $\mathrm{kg}$ of oil feedstock).

${ }^{d}$ Glycerol generated in the biodiesel production from Fatty acids (FA) extracted from biomass (conversion rate of $0.1 \mathrm{~kg}$ per $\mathrm{kg}$ of oil feedstock).

e Ethanol conversion rate of 0.61 per $\mathrm{kg}$ of total carbohydrates.

${ }_{\mathrm{g}}^{\mathrm{f}}$ Methane production rate of 2401 per kg of biomass [49].

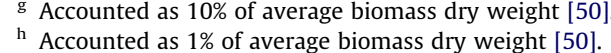


tential biodiesel quality generated by such strains. This preliminary biodiesel quality estimation is only helpful as a means to improve culturing conditions and guarantee commercial application. Overall, this research has shown that mixotrophically grown $C$. vulgaris and $B$. terribilis can generate fatty acids that will produce a biodiesel with good quality.

For both strains, the condition that produced at the same time the highest FA productivity and MUFA concentration was the treatment with $50 \mathrm{mM}$ of glycerol. Such results when applied to the production system show a very promising outcome, in which quantity and quality of biodiesel can be achieved simultaneously. This research has shown that mixotrophically produced fatty acids can generate a biodiesel with good quality for both strains. The estimation shows a production of lipids (FA) of about 122 or $420 \mathrm{~kg}$ per year. Although such values may not sound significant at first glance, this is the potential production of a small-scale operating plant.

\section{Conclusion}

This research shows the positive effect of coupling a WWTP effluent with glycerol for supporting mixotrophic production of $C$. vulgaris and $B$. terribillis. The best performances, assessed as biomass and fatty acid productivities, were achieved using mixotrophic growth at glycerol concentration of $50 \mathrm{mM}$. Likewise, the total composition of fatty acids in each strain at glycerol supplementation of $50 \mathrm{mM}$ showed to be the best profile for the generation of a good quality biodiesel. These findings identify this biological process as a very good alternative for combining wastewater treatment to algal biomass derived energy production. Another important advantage of such a process is a clear improvement on nutrient removal ( $\mathrm{N}$ and $\mathrm{P}$ ) to concentration levels below the threshold suggested by the EU directive. A year round productivity was estimated, showing that such a mixotrophic system can generate biomass yields of 5.6 and 13.5 tons $\mathrm{y}^{-1}$, for $C$. vulgaris and $B$. terribilis, respectively. The volume of glycerol required for sustaining such a production is of about $163 \mathrm{~kg} \mathrm{y}^{-1}$. Several biorefinery options are available for microalgae biomass, but the biodiesel production is being considered as the most suitable for C. vulgaris and B. terribilis, respectively. Therefore, this research suggests that enhanced performance and profitability of a WWTP can be achieved coupling algal biomass production as energy feedstock with effluent post-treatment.

\section{Acknowledgments}

This work was funded by Grants no. 574712/2008-9 and 551134/2010-0 from the Conselho Nacional de Desenvolvimento Científico e Tecnológico (CNPq) of the Brazilian Ministry of Science and Technology (MCT). The authors would like to EMBASA S/A, Empresa Baiana de Águas e Saneamento, for supplying the wastewater samples.

\section{References}

[1] UNO. The United Nations World Water Development Report 3. WATER IN A CHANGING WORLD; 2009.

[2] Chan YJ, Chong MF, Law CL, Hassell DG. A review on anaerobic-aerobic treatment of industrial and municipal wastewater. Chem Eng J 2011;155(1):1-18

[3] Carey RO, Migliaccio KW. Contribution of wastewater treatment plant effluents to nutrient dynamics in aquatic systems: a review. Environ Manage 2011;44:205-17.

[4] Rawat I, Kumar RR, Mutanda T, Bux F. Dual role of microalgae: phycoremediation of domestic wastewater and biomass production for sustainable biofuels production. Appl Energy 2011;88:3411-24.

[5] Lam MK, Lee KT. Microalgae biofuels: a critical review of issues, problems and the way forward. Biotechnol Adv 2012;30(3):673-90.
[6] Li Y, Zhou W, Hu B, Min M, Chen P, Ruan RR. Effect of light intensity on algal biomass accumulation and biodiesel production for mixotrophic strains Chlorella kessleri and Chlorella protothecoide cultivated in highly concentrated municipal wastewater. Biotechnol Bioeng 2012;109(9):2222-9.

[7] Park JBK, Craggs RJ, Shilton AN. Wastewater treatment high rate algal ponds for biofuel production. Bioresour Technol 2011;102:35-42.

[8] Oswald WJ, Gottas HB. Photosynthesis in sewage treatment. Am Soc Civ Eng 1957;2849:73-105

[9] Benneman JR, Miyamoto K, Hallebeck PC. Bioengineering aspects of biophotolysis. Enzyme Microb Technol 1980;2:103-11.

[10] Liang Y. Producing liquid transportation fuels from heterotrophic microalgae. Appl Energy 2013;104:860-8.

[11] Cerón-García MC, Macías-Sánchez MD, Sánchez-Mirón A, García-Camacho F, Molina-Grima E. A process for biodiesel production involving the heterotrophic fermentation of Chlorella protothecoides with glycerol as the carbon source. Appl Energy 2013;103:341-9.

[12] Wijffels R, Barbosa M. An outlook on microalgal biofuels. Science 2010;329:796-9.

[13] Nascimento IA, Marques SSI, Cabanelas ITD, Pereira SA, Druzian JI, Souza CO, et al. Screening microalgae strains for biodiesel production: lipid productivity and estimation of fuel quality based on fatty-acids profiles as selective criteria. Bioenergy Res 2013;6:1-13.

[14] Amaro HM, Guedes AC, Malcata FX. Advances and perspectives in using microalgae to produce biodiesel. Appl Energy 2011;88:3402-10.

[15] Sawayama S, Inoue S, Yokoyama S. Continuous culture of hydrocarbon-rich microalga Botryococcus braunii in secondarily treated sewage. Appl Microbiol Biotechnol 1994:41:729-31.

[16] Chisti Y. Biodiesel from microalgae. Biotechnol Adv 2007;25:294-306.

[17] Chisti Y, Yan J. Energy from algae: current status and future trends Algal biofuels - a status report. Appl Energy 2011;88:3277-9.

[18] Lee Y. Algal nutrition: heterotrophic carbon nutrition. In: Richmond A, editor. Handbook of microalgal culture: biotechnology and applied phycology. Blackwell Publishing; 2004. p. 116-24.

[19] Pérez-Garcia O, De-Bashan LE, Hernandez JP, Bashan Y. Efficiency of growth and nutrient uptake from wastewater by heterotrophic, autotrophic, autotrophic and mixotrophic cultivation of Chlorella vulgaris immobilized with Azospirillum brasiliense. J Phycol 2010;46:800-12.

[20] Sydney EB, da Silva TE, Tokarski A, Novaka A, de Carvalho JC, Woiciecohwski AL, et al. Screening of microalgae with potential for biodiesel production and nutrient removal from treated domestic sewage. Appl Energy 2011;88:3291-4.

[21] Liang Y, Sarkany N, Cui Y. Biomass and lipid productivities of Chlorella vulgaris under autotrophic, heterotrophic and mixotrphic growth conditions. Biotechnol Lett 2009;31:1043-9.

[22] Tanoi T, Kawachi M, Watanabe MM. Effects of carbon source on growth and morphology of Botryococcus braunii. J Appl Phycol 2011;23:25-33.

[23] Cerón García MC, Fernández Sevilla JM, Acién Fernández AG, Molina Grima E, GarcíaCamacho F. Mixotrophic growth of Phaeodactylum tricornutum on glycerol: growth rate and fatty acid profile. J Appl Phycology 2000;12:239-48.

[24] Johnson TD, Taconi KA. The glycerin glut: options for the value-added conversion of crude glycerol resulting from biodiesel production. Environ Progress 2007;26(4):338-48.

[25] ORGANIZATION FOR ECONOMIC COOPERATION AND DEVELOPMENT; FOOD AND AGRICULTURE ORGANIZATION OF THE UNITED NATIONS (OECD/FAO). Agricultural Outlook 2009-2018.2009 Report. 95 p. <http://pt.scribd.com/doc/ 58616471/OECD-Agri-Outlook-09-18>.

[26] Chen Y, Walker TH. Biomass and lipid production of heterotrophic microlgae Chlorella protothecoides by using biodiesel-derived crude glycerol. Biotechnol Lett 2011;33:1973-83.

[27] Metzger P, Largeau C. Botryococcus braunii a rich source for hydrocarbons and related esther lipids. Appl Microbiol Biotechnol 2005;66:486-96.

[28] Rao Rango A, Sarada R, Ravishankar GA. Influence of $\mathrm{CO}_{2}$ on growth and hydrocarbon production in Botryococcus braunii. J Microbiol Biotechnol 2007;3:414-9

[29] Bligh EG, Dyer WJ. A rapid method of total lipid extraction and purification. Can J Biochem Physiol 1959;37:911-7.

[30] Bradford MM. A rapid and sensitive for the quantitation of microgram quantities of protein utilizing the principle of protein-dye binding. Anal Biochem 1976;72:248-54.

[31] Joseph JD, Ackman RG. Capillary column gas chromatographic method for analysis of encapsulated fish oils and fish oil ethyl esters Collaborative study. J AOAC Int 1992;75(3):488-506.

[32] APHA (American Public Health Association). Standard methods for the examination of water and wastewater. APHA, Washington, DC; 1995.

[33] Bird RB, Armstrong RC, Hassager O. Dynamics of polymeric liquids. John Wiley; 1987.

[34] Chinalia FA, Killham Kenneth Stuart. 2,4-Dichlorophenoxyacetic acid (2,4-D) biodegradation in river sediment of northeast-Scotland and its effect on the microbial communities (PLFA and DGGE). Chemosphere 2006;64(10):1675-83.

[35] Cabanelas ITD, Ruiz J, Arbib Z, Chinalia FA, Garrido-Perez C, Rogalla F, et al. Comparing the use of different domestic wastewaters for coupling microalgal production and nutrient removal. Bioresour Technol 2013;131:429-36.

[36] Ruiz J, Álvarez-Díaz PD, Garrido-Pérez C, Barragán J, Perales JA. Performance of a flat panel reactor in the continuous culture of microalgae in urban wastewater: prediction from a batch experiment. Bioresour Technol 2013;127:456-63. 
[37] Ramos MJ, Fernández CM, Casas A, Rodriguez L, Pérez A. Influence of fatty acids composition of raw materials on biodiesel properties. Bioresour Technol 2009; $100: 261-8$

[38] Banerjee A, Sharma R, Chisti Y, Banerjee UC. Botryococcus braunii: a renewable source of hydrocarbons and other chemicals. Crit Rev Biotechnol 2002;22(3):245-79.

[39] Kalacheva GS, Zhila NO, Volova TG, Gladyshev MI. The effect of temperature on the lipid composition of the green alga Botryococcus. Microbiology 2005;71(3):286-93.

[40] Godos I, Blanco S, García-Encina PA, Becares E, Muñoz R. Long-term operation of high rate algal ponds for the bioremediation of piggery wastewaters at high loading rates. Bioresour Technol 2009;100:4332-9.

[41] Ruiz J, Álvarez P, Arbib Z, Garrido C, Barragan J, Perales JA. Effect of nitrogen and phosphorus concentration on their removal kinetic in treated urban wastewater by Chlorella vulgaris. Int J Phytoremediation 2011;13:884-96.

[42] Voltolina D, Gómez-Villa H, Correa G. Growth of Scenedesmus sp. in artificial wastewater. Bioresour Technol 1999;68:265-8.

[43] González C, Marciniak J, Villaverde S, León C, García PA, Muñoz R. Efficient nutrient removal from swine manure in a tubular biofilm photo-bioreactor using algae-bacteria consortia. Water Sci Technol 2008;59(1):95-102.
[44] Cordell D, Drangert J, White S. The story of phosphorus: global food security and food for thought. Global Environ Change 2009;19:292-305.

[45] Singh A, Olsen SI. A critical review of biochemical conversion, sustainability and life cycle assessment of algal biofuels. Appl Energy 2011;88:3548-55.

[46] Rawat I, RanjithKumar R, Mutanda T, Bux F. Biodiesel from microalgae: a critical evaluation from laboratory to large-scale production. Appl Energy 2013;103:444-67

[47] Wanga L, Yu H. Biodiesel from Siberian apricot (Prunus sibirica L.) seed kernel oil. Bioresour Technol 2012;112:355-8.

[48] Ruiz-Marin A, Mendoza-Espinosa LG, Stephenson T. Growth and nutrient removal in free and immobilized green algae in batch and semi-continuos cultures treating real wastewater. Bioresour Technol 2010;101:58-64.

[49] Ras M, Lardon L, Bruno S, Bernet N, Steyer JP. Experimental study on a coupled process of production and anaerobic digestion of Chlorella vulgaris. Bioresour Technol 2011;102:200-6.

[50] Grobelaar JU. Algal nutrition: mineral nutrition. In: Richmond A, editor Handbook of Microalgal Culture: Biotechnology and Applied Phycology. Oxford: Blackwell Publishing; 2004. p. 97-115. 